\title{
Breast Diffuse Large B-Cell Lymphoma
}

National Cancer Institute

\section{Source}

National Cancer Institute. Breast Diffuse Large B-Cell Lymphoma. NCI Thesaurus. Code C40375.

A diffuse large B-cell lymphoma that arises from the breast. It is the most common type of primary breast lymphoma. 